\title{
Learn Pencak Silat Like Write a Book :
}

\section{Innovative Training Method Development to Increase HOTS CREATIVITY in the Industrial Revolution Era 4.0}

\author{
Cerry Kartika Trizkyana ${ }^{1, *}$ Siswantoyo Siswantoyo ${ }^{1}$ \\ ${ }^{1}$ Graduate Program in Sports Coaching Education, State University of Yogyakarta \\ *Corresponding author. Email: Cerrytrizkyana@gmail.com
}

\begin{abstract}
To train fighters to always learn Pencak Silat comfortably, there is an increase in analytical, evaluation and creativity skills from an early age so that they are able to improve higher-order thinking skills. The purpose of this research is to improve the movement skills and creativity of the fighter in learning Pencak Silat. The research method uses (Mix Methods) which is a combination of quantitative research and qualitative research. The population in this study is the Pencak Silat College in the DIY region. The sample is 24 people with 12 people in each college. The result of this research is that the data is declared to have the same variance if the significance level is greater than 0.05. Tests were carried out using SPSS 26.0. In conclusion, with the Alphabet method, the fighter will be freer in expressing his creative ideas through a series of motions where the material is obtained according to the level/belt that is being or has been undertaken.
\end{abstract}

\section{Keywords: Pencak silat, Creativity learning, Alphabet method}

\section{INTRODUCTION}

Sport is a physical activity that provides many benefits for the body such as training the body's muscles and maintaining a healthy body. According to Giriwijoyo (2005:30) sport is a series of regular and planned exercise that is carried out consciously to improve functional abilities. Sports are indirectly required to be able to think at a high level. The reason is, one must be able to understand, perform, practice, analyze, evaluate, and create creativity. An example of a sport that teaches us to think at a higher level is Pencak Silat.

Of the many branches, Pencak Silat is one of the martial arts sports that can be categorized as very well known to the people of Indonesia. This is because Pencak Silat is an original Indonesian martial art sport which is still being preserved and will continue to be preserved as one of the nation's cultures.

Sukowinadi in Siswantoyo (2016:4) states that Pencak comes from the Javanese language consisting of the words "Pen" which means right and "Cak" means application / cak-cak-ane. Thus, Pencak is the proper application of martial arts skills, both how and how to use them. While the word Silat is defined as a summary of the word "Silaturahmi" which means brotherhood. Pencak Silat means a self-defense system in the application of kemahirannnya do it right, fast to martial arts and sparring with based aspects of ethical, technical aesthetic which is intended to tighten the rope Hospitality.

In Indonesia, there are many schools of Pencak Silat such as PerPI Harimurti, Tapak Suci, Self Shield, PSHT, Unity of Hearts and so on. Most of the Pencak Silat Universities use the method of giving college material. Until now, there is no effective and efficient method to increase cognitive ability from low level to high level cognitive ability. So that the fighter will be able to not only understand, perform, practice Pencak Silat movement skills, but it is hoped that the fighter will be able to analyze, evaluate and create. The innovation of this method can be adopted from the method of learning to write the alphabet.

In the millennial era, there are still many young people who do not have a high level of creativity. Currently, these millennials are still at the stage of only being able to understand, do and practice 
development (develop), implementation (implement) and evaluation (evaluate).

The population of this research is Pencak Silat College in DIY. In developing the product, the research subjects were youth-level fighters, who would be given special learning using the Alphabet Method and Kick Method innovation, a total of 24 people with 12 people from each college. The object of research is the Pencak Silat College in the DI Yogyakarta area.

This research will focus on developing Pencak Silat learning method with alphabet writing approach. The dependent variable that will be revealed in this study is Pencak Silat movement skills, and the ability of creativity to create a series of varied movements / moves, having a richness of motion, correctness of technique, stability of motion.

\section{RESULTS}

The analysis was carried out at the beginning of the study by collecting relevant data. At this stage, data collection related to the Pencak Silat learning method was carried out by compiling a questionnaire and data collection was carried out offline by filling out questionnaires to the respondents, and carried out with the help of the online google form application, so that quite a lot of data was found to be analyzed. At Design stage concrete steps taken from this stage are as follows: 1). Based on the conclusion of the analysis of the alphabet method, 2). Determine the approach that will be used to have an effect on the process of learning the alphabet method on students' thinking and creativity. At the development stage, it is done by designing an alphabet book, and making instruments to measure children's social attitudes, then validated by experts. After obtaining proper validation results, then the next step is limited testing. In the implementation phase, a broad trial was conducted involving a sample of 24 people. The wide trial used a pretest - posttest control group design experimental design. The evaluation stage is carried out by evaluating the level of thinking and creativity of students after using the alphabet method. After the evaluation, the final product of the development model will be obtained and dissemination will be carried out by making an alphabet guide book for higher order thinking skills (HOTS), scientific articles published in the Sinta journal, and video tutorials for learning Pencak Silat with the alphabet method.

Inferential statistics are used to test the effectiveness of the product. The inferential statistic used in the limited trial is the t-test. The t-test was used to determine the effectiveness of learning 
products in improving social attitudes. The product effectiveness test was analyzed using t-test with a significance level of $5 \%$. The analysis prerequisite test includes normality test and homogeneity test. Normality test aims to determine whether a data is normally distributed or not and homogeneity test is carried out to test whether or not the variance of two or more distributions is the same. (Santoso, 2018: 49). The data is declared to have the same variance if the significance level is greater than 0.05 . Tests were carried out using SPSS 26.0

\section{DISCUSSION}

Based on the results of an interview with the swordsman council, Mr. Sardjono, he said that the Alphabet Method was first developed in the 1970s, this method requires thinking skills so that students are more active and creative in compiling a series of movements. This is reinforced by the opinion of Mr. Suwandi that physical movement skills, mature technical abilities and supported by intelligence and a high level of creativity can create harmony in life. So that in accordance with the philosophy of life, this balance will be very necessary and will make strategic steps to achieve the desired target.

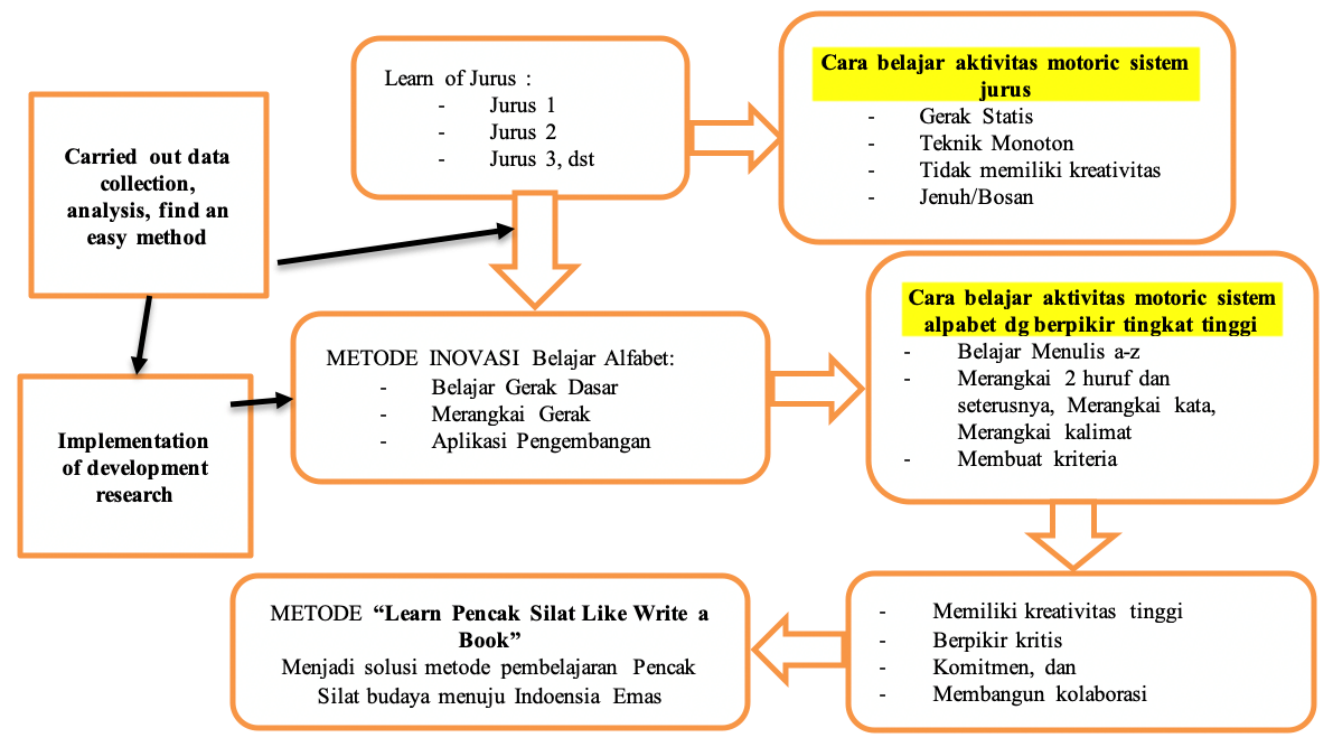

Figure 1. Learn pencak silat like write a book

Prof. Dr. Siswantoyo said that the Alphabet Method is a Pencak Silat training method that teaches basic techniques like someone writing the letters of the alphabet az. Then students are given the freedom to string motions like they are stringing words into a sentence which then strings the sentences into a narrative according to the creativity of the students. Of course, the creativity of each student is different. By the time students assemble the motion, they are able to understand, perform, practice as well as analyze, evaluate, and create a series of movements based on the basic techniques that have been taught. So that students are at the cognitive level of the HOTS (Higher Order Thinking Skill) level. This training method is expected to increase the creativity of higher-order thinking.
The element of motion in the sport of Pencak Silat contains artistic value, as well as highlighting the beauty of motion. According to Johansyah Lubis (2004, pp.8-33) there are several elements of motion which are described in detail, including (1) horses, (2) pairs of postures, (3) step patterns, (4) defending, (5) attack, (6) catch.

According to Aristotle (Hergenhanh \& Olson, 2008, p.34) formulating the law of association, that experience or memory of an object tends to cause memories of something similar to that object. It further explains that Aristotle considers sense impressions to be the basis of all knowledge. In line with this theoretical thinking that Pencak Silat movement skills require various senses involved in it. 
Children will be more motivated in carrying out activities if the environment is conducive to learning. A supportive play atmosphere such as friends, the type of activity, the place where the activity is felt by the child will really give a positive boost.

According to Gestalt (Hergenhanh \& Olson, 2008, p.330) memory trace is a physical system that produces field strengths obtained from past experiences that will affect all similar processes in the future. The Gestalt explanation of memory traces provides an overview of this development that is given or implanted in relation to cognitive, affective and psychomotor aspects.

Cognitive level is the thinking ability of a student individually or in groups which is divided into two levels, namely Low-Level Thinking Ability (LOTS) which shows low thinking ability which includes understanding, implementing and practicing. Higher Order Thinking Ability (HOTS) shows a higher level of ability which includes analysis, evaluation and creation.

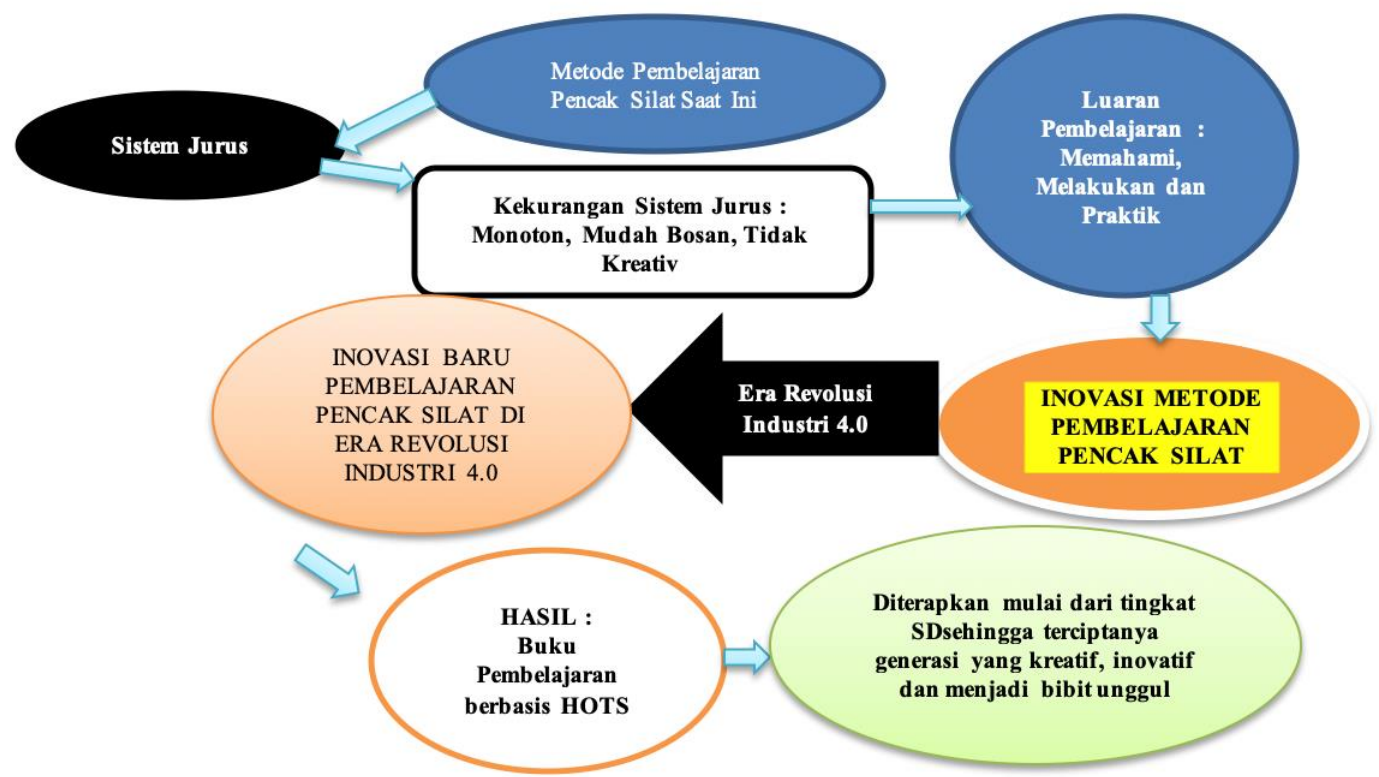

Figure 2. New innovation of learn pencak silat

\section{CONCLUSION}

Pencak Silat is known as a martial sport that emphasizes high creativity. The hope is that with this innovation which will be branded under the name LEARN PENCAK SILAT LIKE WRITE ALPHABETH, which is based on Higher Order Thinking Skills (Analysis, Evaluation, Creativity), all fighters can be more creative in learning Pencak Silat. Of course not only that, this learning method is applied starting from the elementary level so that it creates a generation that is creative, innovative and becomes superior seeds. So that the hope is not easily bored, not monotonous and faster growing. With this Alphabet method, the fighter will be freer in expressing his creative ideas through a series of movements where the material is obtained according to the level/belt that is being or has been undertaken.

\section{REFERENCES}

1. Giriwoyo, YS Santosa. 2013. Sports Health. Bandung: Rosdakarya Teenagers

2. Lubis, Johansyah. 2004. Pencak Silat: A Practical Guide. Jakarta: PT. King Grafindo Persada.

3. Siswantoyo. 2016. Pencak Silat in the Perspective of Identity, Integrity and Science and Technology in Sports Coaching. Yogyakarta: Yogyakarta State University

4. Sani, Ridwan Abdullah. 2019 HOTS (Higher Order Thinking Skill) Based Learning. Tangerang: Tirta Smart.

5. Kusuma MD, Rosidin U, Abdurahman A, Suyanta, A. (2017). The Devolement of Higher Order Thinking Skill (HOTS) Instrument Assessment in Physics Study. Journal of research $\&$ methods in education. 7(3):1-6.

6. Primayana, KH 2019. Creating Problem-Solving-Based Learning Oriented to Character Building To Create Higher 
Order Thinking Skill (HOTS) Goals for Elementary School Children. Purwadita: Journal of Religion and Culture . 3(2): 85-92Zhou, J. (2015). The value of music in children's enlightenment education. Open Journal of Social Sciens

7. Stephani, MR, Suherman, A, Mulyana RB 2014 The Effect of Inquiry Learning Model on Critical Thinking Ability and Basketball Playing Skills. Educentric. 1(2): 156-170.

8. Siswantoyo S. (2018). Preparation of Norms for Youth Pencak Silat Physical Tests in the Competing Category. Sports Journal . 6(1): 2-10.

9. Mujriah. 2021. Development of the Lombok Traditional Game-Based GOGER Learning Model to Improve the Social Attitudes of Elementary School Students. Proposals. Yogyakarta: Yogyakarta State University.

10. Wibawa RP (2019 The Role of Higher Order Thinking Skill (HOTS)-Based Education at the Junior High School level in the Society 5.0 Era as Determinants of the Progress of the
Indonesian Nation. Scientific Journal of Economics and Learning. 7(2):137-141.

11. Shah FF, Haryani S, Wijayati N. (2016). Team Assisted Individualizaton with Structured Training Methods to Improve Critical Thinking Skills. Journal of Innovative Science Education. 5(1): 10-18

12. Abdullah AH, Abidin N. LZ, Ali M. (2015). Analysis of Students' Errors in Solving Higher Order Thinking Skills (HOTS) Problems for the Topic of Fraction. Asian Social Sciences. 11(21):133-140

13. Lewis A, Smith D. (1993). Defining higher order thinking. Theory Into Practice. 32(2):131-137.Paturusi, A.(2012).Manajemen pendidikan jasmani. Jakarta:Rineka CiptaPeter H. Werner, Lori H. Williams, Tina J. Hall. (2012). Teaching children gymnastics. USA: Human Kinetics. 